\title{
Smurfs, cyborgs and changelings: prospects of human enhancement retrospected
}

\author{
Predrag Krstić • Srđan Prodanović
}

Received: 11 June 2013 / Accepted: 22 August 2013 / Published online: 18 September 2013

(C) The Author(s) 2013. This article is published with open access at Springerlink.com

\begin{abstract}
This article stems from the impression of being condemned to late and moralizing reactions in regard to advances in the life sciences. We suggest a return to a speculative and theoretical approach in posing the question(s) of the limit of possible thinking of the enhanced human. This return allows for the possibility to show, not just inductively, but "clearly and distinctly," the specific justifications and lines of reasoning of anthropocentric prejudice or species narcissism. It also enables us to move freely and precisely along the limits of thinking the human/non-human. In this way, we hope to put forward a few markers or guideposts that would further the debate about notions of human enhancement.
\end{abstract}

This article is the result of the work on the project "Rare Diseases: Molecular Pathophysiology, Diagnostic and Therapeutic Modalities, and Social, Ethical, and Legal Aspects" (project number 41004), the subproject of the Institute for Philosophy and Social Theory "Bioethical Aspects: Morally Acceptable Within the Biotechnologically and Socially Possible", as well as the project "Studying Climate Change and its Influence on the Environment: Impacts, Adaptation and Mitigation" (project number 43007), the subproject of the Institute for Philosophy and Social Theory "Ethics and Environmental Politics: Institutions, Techniques and Norms in the Challenge of Changing the Natural Environment". Both projects are being funded by the Serbian Ministry of Education, Science and Technological Development, within the 2011-2014 funding period.

\section{P. Krstić $(\bowtie)$}

The Institute for Philosophy and Social Theory, University of Belgrade, Sime Igumanova 16, 11000 Belgrade, Serbia

e-mail: krstic@instifdt.bg.ac.rs

P. Krstić

e-mail: prekrst66@gmail.com

\section{S. Prodanović}

The Institute for Philosophy and Social Theory, University of Belgrade, Milice Rakić 45/2, Belgrade, Serbia

e-mail: sprodanovic@instifdt.bg.ac.rs

S. Prodanović

e-mail: srdpro@gmail.com
Keywords Conceptions of enhancement · Biological metamorphosis · Philosophical anthropology $\cdot$ Humanism . Transhumanism

Is there a qualitative difference between modern practices and understandings of human enhancement and previous conceptions for which we rather use the terms "improvement," "perfecting" and the like? The difference in question would primarily or exclusively refer to the methods of achieving the desired goal. Therefore, we can adopt a distinction: on the one hand, the conventional, "natural" ways of bringing about improved abilities in humans like education, training, diet, exercise, even invention of useful tools, external to the body itself; on the other hand, the unconventional ways that rely on the "artificial" means and are now present as tools, internal to the body, literally incorporated, integrated in our bodies [1]. Now, if the difference is only one of degree, the transhumanists are right. If, however, the technologies of human enhancement are about something essentially different from the results produced by effort put into persistent "work on oneself", at least in the repeatedly determined (by the context of community) sense of increasing one's abilities past the level of "species-typical normal functional organization," [2] then bioconservatives, who set the limit at a given point, will sooner or later be right [3]. That limit - not of enhancement, but of the enhanced human - is the subject of this paper.

In its simple and direct formulation, we can pose the question of that limit as follows: to what extent may a human being be modified, yet still be talked about as human, or an enhanced human. The emphasis in question is thus transferred from the inside out, from the way of enhancing to what is being enhanced, from "technology" to "anthropology." However, for this paper it would be sufficient to emphasize the obvious: what is always acted on is "human biology" $[4,5]$ - which then appears as either more fragile and limited, or more complex 
and boundless than previously thought. In our attempt to test if and to what extent it is morally acceptable for modern people to use biotechnologies in order to enhance their cognitive, morphological and procreative capacities, we will mainly rely on the division regarding specific patterns of means of enhancement. Namely, we will try to connect this division with the figures of the "enhanced" that is with the images of a creature inscribed with a feature that, from its very beginning, and exactly as a human, he/she wants to be, such as Übermensch [6], Homo superior [7] More than human [8].

We could say that our paper is an attempt to follow the development of modes of enhancement through already established sciences. "Human biology" was first affected by means of chemistry, then of physics and lastly by means of biology itself. This encroachment of science of life upon life seems to lead to unsuspected and spooky consequences. We see an image of a human being which is not even the offensive vitiation of its "natural" self any longer. Rather, due to the enhancements that have already dissolved its consistency, making it no longer recognizably human (even in aberration), it is no longer affected, nor therefore determined, by the enhancement, making it a vision of something non-human that cannot be further enhanced. The question, however, remains: has "human biology" thus finally been surpassed and has the illusion of its privileged exclusiveness been abandoned? Or, on the contrary, has it just been regenerated and affirmed with regard to the "assigned" and not the "given" element of "perfectibility" in its structure? The historical path we sketch, and the continuity we establish, can also be read as a gradual, astonishing (or farcical) development in executing the belief of humanism that the human is special precisely and entirely because it can become anything it chooses to become.

\section{It gives you wings: the case of chemistry}

Contrary to the current scientific and technological imagination, contemporary bioethical concepts, as well as certain practices of enhancement, may turn out not to be so new in their basic notion. This is particularly true of investment in the possibility of "chemical" enhancement of humans. Even a glance through the history of ethnology is rather sufficient to find myriad practices of using magic potions. From Gilgamesh's quest for immortality, the shamanic and Pythian vapors, the fountain of youth and the elixir of life, the Holy Grail and holy water, to Asterix's, Smurfs' and Red Bull mixtures that give supernatural strength - it seems that a possibility of chemical intoxication for the sake of temporary or permanent "enhancement" represents a civilization archetype and that it is an imperishable motif of diverse textual and visual performances. The wish to regain youth, or more generally speaking, to overcome the natural limitations of the human body, could really be regarded in that sense as "the oldest hope of mankind," as well as a cross-cultural and panhistorical motif, which persists into modernity through scientific projects, such as discovering the human genome [9]. ${ }^{1}$ In that sense, the "scientific" understanding of enhancement only extends the same line of human dreams and attempts, which may be as "authentic" as biological determinacy. However, it does this in a qualitatively different way.

There is something that fundamentally differentiates the modern advocates of enhancement from, for example, alchemists or one of the heroes of One Thousand and One Nights who is searching for the plant of immortality in other worlds the difference is, indeed, in their common Promethean ambition to find the "perfect nature" [10]. There is not any techno-science in the animized and divinized world, nor is there the idea that any kind of tool, which would enhance our capacities, could be produced without a devoted conspiring with supreme forces. There is, of course, such a thing as medical therapeutics, but it is aimed - as it is today, only with a more questionable scope - at removing pathologies that endanger health or limit the level of an individual's functioning below the one that is considered to be "statistically normal" for a species. It leaves, all the while, the structure of the body itself and its functioning unchanged [11, 12]. The Greeks had thus been cautious in strictly distinguishing curative treatments (for example dietetics) from spiritual or physical ascesis (dialectics, paideia). Visions of dramatic or instant enhancement, as well as enhancement added from the outside - if allowed at all - were assigned not to their "technologies," but to mysteries and cults, to artifacts of ancient religions that were unearthed, not fabricated, and possibly to mythical narratives containing a compulsory tragic reminder of the consequences of hubris, like the cases of Icarus and Prometheus. There are images of metamorphosis, but they are a part of another world, a relic that is sought and found by divine mercy or that warrants punishment. The very transformation cannot be reconstructed, it does not have a formula, and even if it did, it would be secret or unavailable; it leaves no trace of the method used nor the possibility of repeat testing, something likely to be considered an offense to the gods.

The idea that it is possible or thinkable to enhance the given biotic with chemistry had undoubtedly been born before bioethics and contemporary enhancement practices. However, from the time humanity regained trust in unlimited human powers in the Renaissance, until perhaps the second half of the $20^{\text {th }}$ century, enhancement was accompanied by an ambivalence: bad conscience was speaking and warning of interference in God's work. We already see this in Faust, but it really blossoms in Gothic novels about "mad scientists." Throughout the genre, we find the notion that scientific research may commit diabolic acts of malevolence.

\footnotetext{
${ }^{1}$ For a convincing argument that neither the age-old nature of this motif, nor its modern persistence necessarily imply its moral justification and social desirability, see [53].
} 
Moreover, these novels could be regarded as "exercises in anti-rationalism", the endeavor to dispute the optimistic belief that things must be valuable only because they are scientific [13]. If we take a look at the pharmacology of Stevenson's Dr. Jekyll, we notice it lacks any physical detail, but has abundant oracular references to a mysterious salt [14]. The scenes of Sherlock Holmes's shrewd illumination or the atmosphere of opium vapors with the creativity of doomed poets coming up are also veiled by mystery and painted in sfumato. The process of creation in Mary Shelley's Frankenstein [15] is presented in a similar manner - without any details - as it is in the films The Golem, Metropolis, Frankenstein and The Bride of Frankenstein [16, 17]. Physical artifacts of "science," all pieces of equipment, all experiments, laboratories, narcotics, rays and similar tools are presented, as a rule, "ambiguously, illogically, and mysteriously, in other words, irrationally." They are linked together incoherently and are justified no better than "material junk of alchemists," if at all $[13,18]$. Still, the conviction remains: science can - perhaps at too costly a price - make a better being.

Now, aside from the undivided and epoch-determined image of metamorphosis, and despite the (partly secret) science-induced, frightening vision of re- or de-generation, the novella features a particular vision of enhancement techniques. It is noteworthy that Dr Jekyll is always present in his experiments on humans. Even when he changes into Mr. Hyde, the change is always transitory and reversible. Not only that, but Dr Jekyll functions as an identity anchor from which Mr. Hyde departs. In that sense, the reader always keeps in mind the true identity of the character (Dr Jekyll), and considers the other a temporary aberration (Mr. Hyde). Chemicals enlarge our powers, enable us to feel a bit of eternal youth and immortality, guarantee happiness or satisfy the curiosity of testing our own limits; however, they do not except for a certain period of time, and even then only through constantly referencing the being which was altered change us structurally. They make us (in)comparably better or different only temporarily.

As Nabokov points out in his essay on Kafka's Metamorphosis: "[T] here is really nothing especially pathetic or tragic about Jekyll. We enjoy every detail of the marvelous juggling, of the beautiful trick, but there is no artistic emotional throb involved, and whether it is Jekyll or Hyde who gets the upper hand remains of supreme indifference to the good reader"[19]. Here Nabokov stresses the fact that the reversibility of chemical enhancement robs Stevenson's novella of its moral tension. Unlike the truly tragic character of Gregor Samsa whose metamorphosis is in essence an irreversible progressive mutation of his human substance, ${ }^{2} \mathrm{Mr}$. Hyde's is only a temporary "personality disorder" of Dr. Jekyll.

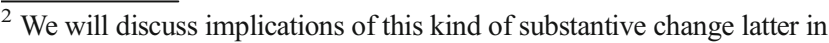
the paper.
}

Frankenstein's monster is another story entirely. He is galvanized, patched up, cobbled or put together, reconstructed. We are no longer dealing with a bit of herbal enhancement of the human body. The monster could stand at the beginning of a different chapter, representing the notion of the body, not chemically altered, but engineered or constructed. The image of Adam in Mary Shelley's novel is actually one of inconstancy and instability, but we know that he is constructed from body tissue, that is, the biotic, in an attempt of his creator to repeat the pattern of his own creation (through other means). However, the means of his creation, the intervention mechanism, as well as the display of its outcome, anticipate something completely different from chemical enhancement of the organic.

\section{Hasta la vista, baby: the case of mechanics}

Computer technology has made the "cybernetic organism" visually persuasive and mentally competent. With a more subtle presentation it has acquired a credibility lacking in previous monsters of science fiction. ${ }^{3}$ Here too, we can make a distinction between two forms: the hero and the collective [20]. The narrative of the hero cyborg, as in the movies Terminator 2: Judgement Day and RoboCop is obvious. In the background story, their human subjects had been disembodied and transformed by technology into a new enhanced whole. At first the hero resists his new identity, but in the end he accepts and uses his fragmentariness as an element of his enhanced, "cyborg" body and self.

The narrative of a cyborg as a collective - lacking any idea of individuality or unique self - is most prominently shaped in the character of Borg in the television series Star Trek: The Next Generation and later in Vyager. Academic literature has sometimes seen Borg as a neo-communist community of androgynous humanoid individuals, connected to one another through bioengineering and other advanced technologies, as well as an embodiment of the fascist idea of complete suppression of individualism for the benefit of the collective [21, 22]. Borg is, in any case, a fascinating union of individual cyborgs in a unanimous hive-like oneness. In search of perfection, Borg keeps reproducing itself by absorbing into its being all species from the universe that advance its structure.

What is always at stake in encounters with (cy)borgs, meaning, with any sort of inorganic infection of the biotic, is "humanity". The entire seven-season television series Star Trek: The Next Generation (1987-1994), in which Borg and

\footnotetext{
${ }^{3}$ Considering the subject of this paper - the limit of thinkability of an enhanced human being - it seems that science fiction, primarily understood as a narrative reflective experiment $[54,55]$, may be the most appropriate medium for unmasking characters that are standing at that boundary.
} 
various "mixed" sorts appear, describes the arc from humanity "on trial" in the first episode, to its "exhumation" in the final episodes [23]. Therefore it seems that cyborgs of popular science fiction are created in advance to imitate human life but remain outside of it, and thus serve as a counterbalance to humanity, one which emphasizes human desirability. They are "marking the boundaries of humanness ... against technology" [24, 25]. This is an old paradigm, bordering on cliché, in which characters ranging from Baum's Tin Man to the Terminator nostalgically and mournfully celebrate a humanity which they resemble closely but to which they do not belong. [26].

In that sense, the image of a cyborg which we find in popular culture perfectly illustrates deep-seated countertechnological assumptions of humanity. But is perfectibility not at the very core of human existence? Is betterment not actually something fundamentally human, even if we use unconventional means to achieve it? If we agree that our evolution is desirable and finally at hand, why discredit in advance any type of enhancement? Visions of our cybernetic future are in that sense absolutely compatible with our emancipatory intention to attain directed evolution that would be informed by our scientific knowledge. J. B. S Haldane and John Bernal [27] where among the first authors to see that science can become one of the causal powers that purposefully directs the otherwise slow and contingent process of Darwinian evolution. ${ }^{4}$ What underlies the notion of the cyborg is the idea that science can provide some kind of "clean slate" or cleared space for a radical change of humans and their future [28].

Moreover, the future has already begun. We have suddenly found out that we ourselves are cyborgs - mechanized constellations that have abandoned, although refuse to admit so, the ancient determinant of unique embodiment, personality and subjectivity. As of not long ago, but certainly for some time, we have been "post-human": physically and/or mentally reconstructed to overcome (previous) human limitations. That quite a high number of us qualify as cyborgs through artificial implants or technical devices compensating for our bodies' limitations is not at stake here; no prosthesis is necessary to satisfy the condition of being posthuman - changing the way we think about ourselves is sufficient [29]. The decisive turn in determining ourselves, both as individuals and as a species,

\footnotetext{
${ }^{4}$ For instance, Bernal is keen to remind us that " $[\mathrm{u}]$ nder the pressure of environment or whatever else is the cause of evolution, nature takes hold of what already had existed for some now superseded activity, and with a minimum of alteration gives it a new function. There is nothing essentially mysterious in the process: it is both the easiest and the only possible way of achieving the change. Starting de novo to deal with a new situation is not within the power of natural, unintelligent processes... $[\mathrm{M}]$ en may well copy the process, in so far as original structures are used as the basis for new ones, simply because it is the most economical method, but they are not bound to the very limited range of methods of change which nature adopts" [56].
}

was the invention of electronic computers. From that point on we have been noticing similarities and tensions between living beings and computer systems, artificial and natural life forms, traditional Western ideas of human identity and the disturbing direction toward cyborgs, which humanity seems to have taken. And while some people are delighted with this change and can hardly wait for the "mind uploading" or "mind melt," others shudder at the thought of a dreadful monster hatching out of the very machines that used to be obedient [30]. In other words, a change without precedent has already occurred, which seems to be endangering our species in a dramatic and lawful way: the appearance of artificial life could lead to the next evolutionary stage, in which we would turn out to be, at best, "out-of-date." If the name of the game is processing information, it is only a matter of time until intelligent machines replace us as our evolutionary heirs. Whether we decide to fight them or join them by becoming computers ourselves, the days of the human race are numbered [29]. ${ }^{5}$

However, the key and probably the best-known and most far-reaching moment in theoretical apologia for cyborgization of man is certainly the establishment and apotheosis of the (cultural) cyborg's status in the famous "A Cyborg Manifesto," written by Donna Haraway in the mid 1980s. She resolutely affirms the influence of technology on human life and concludes that the very image of the cyborg offers a "way out of the maze of dualisms in which we have explained our bodies and our tools to ourselves" [31]. As inherently pluralistic, as a place that incorporates dualism of people and their material surrounding, the cyborg refuses to inherit the Western dualistic strategy of identity that hierarchically confronts male and female, people and beasts, self and other, etc. Further, the cyborg lends its image to a feminist mankind, which would like to depose the universal male face of its modernistic figure [32]. Thus the cyborg has the capacity, as a "root metaphor" of modern human identity, not only to correct the delusions of that identity but also to encourage a responsible awareness of unrestrained interaction with the material and social environment [31].

In the world in which we live, where all of us are "chimeras, theorized and fabricated hybrids of machine and organism" [31], in the biotechnologically surfeited world of technoscience, "[i]n a world where the artifactual and the natural have imploded, [and where] nature itself, both ideologically and materially, has been patently reconstructed" - in such a world, ontologically speaking, biology cannot, and,politically, must not (anymore) represent "culture-free universal discourse" [33]. Its taxonomy moves and brings the genealogical origin of species into question, liberating it from the ever "bloody" concept of kinship.

\footnotetext{
${ }^{5}$ For a history of the cyborg-ruled posthuman perspective of "participatory evolution" or voluntary ruling of evolution aimed at removing "biological limitations" - leaving out Hayle's trepidation of the impact of biotechnology on the human race - see [57-59].
} 
With the cyborg metaphor, the exoticized non-biological body of "cyberfeminism" substitutes the carnal body of classical feminist theory: cyborgs are not born of a woman, they cannot reproduce, but they break all blood, racial, species or population ties in the most insidious way [34].

\section{Lost case: biology}

After theoretical investment in emancipation by cyborg (whose posthumanity, disembodied, deprived of complexity, bloodless, without family ties, turns out to be ominously curative of human awkwardness), provided that we outlive chemical and technical intervention and influence, we are left with the biotic attempts at human alteration. There are genetic mutations, clones and even something (perhaps most) horrible: a complete decomposition and amorphization - for the sake of the possibility of a formless existence. Our resistance to biological remodeling of life is probably fiercer than to episodes of poison induced mania or systematic poisoning by steroids, fiercer even than the technophobic resistance to numerous implants and prostheses we eventually "get used to." Even though what we consider the limit of the human has been stretched through intoxication or technology, and is now difficult to define or establish, we are still anxious about gene manipulation. Genetic alteration is still placed automatically and unconditionally beyond the acceptable limit, even dealing with soy DNA, no less its human counterpart.

"The chemical or physical inventor is always a Prometheus". In pointing out a new kind of unprecedented insult, Haldane said, nearly a century ago, that there is no great invention, from fire to flying, which has not been "hailed as an insult to some god". But if every physical and chemical invention is a blasphemy, every biological invention is a "perversion". Invariably, an observer of a culture alien to any such novelty would perceive the invention as indecent and unnatural [35].

Modern terms for this indecency are "artifact" and "artifactual", in contrast to "nature" and "natural" - at least before the old danger of blurring the lines between them [36, 37]. But it is very likely that the alteration here is also inevitable: we should get used to the loss (at least to a certain degree) of our own autochthony, and resistance is, just as before Borg, futile. There seems to be a point, which we are approaching, at which we will no longer be able to speak about autochthony, modification or cloning of somebody, that is, about that "somebody" as an anchor of personal or species identity, placed in a body, memory, mind or something else. That point is perhaps comparable to the "final frontier" from the prologue of Star Trek. The frontier - now set by the enemy who also symbolizes it - still remains insurmountable and disforming. It is the literal loss of form or of memory of previous form; it is the possibility of assuming any form while at the same time, losing one's own; it would be the transfer to the next level of protobiological existence - paradoxically proving a point in favor of human excellence.

The other name for this enemy is a "shapeshifter" or "metamorph". The transformations "he" undergoes are by definition here understood completely differently from the ones that have occurred since time immemorial in fairy tales, mythologies, folklore, epic literature, even in sci-fi literature. They are different mostly for being without the very substance needed to talk about "transubstantiation." It is one thing to change a frog or beast into a prince, or a man into a werewolf; or to change from Zeus and later wizards, evil witches and warlocks into whatever men, women or animals they like (and revert back) [38, 39]. It is a completely different thing to be an "entity" similar to the sea-god Proteus: continuous, elusive and unreenforcable change. In the case of Proteus, change itself is the entity's "nature." He is the sea as a liquid and flowing quality of unbounded an indeterminable water, inconsistency itself, and the ability to take myriad shapes and mold oneself universally [40].

Transhumanism, in its original definition offered by Julian Huxley in 1957 - "man remaining man, but transcending himself, by realizing new possibilities of and for his human nature" [41] - is here definitely thrown out the window to be replaced with one beyond the transitional period, because the former is still oriented toward that which it resists. Metamorph is rather the lemma of a genuine posthumanism that is no longer even affected by humanism. In Terminator 2 , the nanomorph $\mathrm{T}$ 1000 is the main opponent of the previous generation of terminators, the automated, mechanized T-800, taking the human form of Arnold Schwarzenegger. This older version could even be "humanized," given that he starts out as a programmed killer in the first Terminator film from 1984 but turns pro-human in the later installments, where he is a repaired, avuncular figure, protecting the innocent from the now much more gruesome danger of (ex)termination at the hands of the T-1000. The evil character made of practically indestructible liquid alloy metal is convincingly portrayed by the actor Robert Patrick. However, it really does not matter who plays the role, except for the figurally and substantially set eyes of the viewers, for whom "he" must have some basic form. Meanwhile, he assumes innumerable forms, doing so to perfection, even being able to direct the flow of his shapeless form. This is actually his character: a character without one character, polycharacter, character of metamorph, one that has no form, essence or structure, and can assume any form from his indeterminate "self."

Let us imagine now that the point in question is not, fundamentally, almost perfect counterhuman likeness nor reinforcement of endurance to the point of indestructibility. Let us imagine that it is not the inorganic, liquid metal alloy that assumes characteristics of biological life. Let us imagine that there is such a life, such biotics. Unlike the mechanized case of (cy)Borg [22], the third series of Star Trek, Deep Space 9 features an example of the notion of post-cybernetic metamorphosis [42] and biologization of the enemy. There are "Changelings," who are 
determined to avenge their ancestors and destroy all "Solids," all non-Changelings, everyone that has a defined form. They are the only biological organisms in the Star Trek universe that can be whatever they want: various "solid" forms of life, but also a fire, fog, inanimate objects, operational computer devices, light reflections, etc. In their "natural" state, they are - a familiar picture indeed - some kind of rippling liquid collective life form, a manifold united into an ocean of calm waves, a biological orbifold. They have a faint feeling of individual identity and like to think of themselves as a drop in the "Great Link," a direct and overall connectedness with the life of their species, in which they are united. Changelings appear as pure protobiological mixture, a (more) dense (compared to Proteus) liquid or gelatinous mass, whose appearance is as ancient as life itself and a fundamental element of its composition.

It seems as though Changelings represent the final frontier of both the human and its vision of enhancement, the frontier of thinkability of the enhanced human where it still remains human. But at the same time, it looks as though the contemporary "enhancement movement" has done nothing more than taken both humanists and transhumanists seriously by radicalizing the fears of the first and hopes of the second. To wit, the movement has taken both sides' emancipatory promises of abolishing any ideological misleading at face value, even that which places the "human" as the latest ideologeme. Those promises leads us back, in a way threatening to all traditional (sup)positions - this time with full awareness of the consequences of transhumanism - to the initial question of the entire humanist project. $^{6}$

Let us take seriously Pico della Mirandola's notion of the human $[43,44]$ as a "creature of indeterminate image" and as "the free and extraordinary shaper" of his own image, placed by God outside the world so that it could "fashion" itself in the form it preferred. Further, let us affirm the privileged belief, not in theistic terms, but which nonetheless runs through the history of philosophy and anthropology as a secret code word passed from ear to mouth, that humans are autonomous and self-creating beings, unrestricted by their own condition and in principle free architects of their own destiny [45-51]. But if this is true, why place a limit at all on humanity's quest for new forms and modes of enhancement leading to new forms and modes of existence? On the other hand, if these claims are not true, might there be a line of demarcation, some essential content (even in the "soft sense"), which would render an

\footnotetext{
${ }^{6}$ According to its own valid self-understanding, transhumanism is actually an offshoot of the humanistic movementI. It differs from the humanistic mainstream in focusing upon the technological moment of enhancing the human condition [60]. In that sense it would rather be the futuristic "ideology" of (post)humanism that affirms the possibility as well as the desirability of "repairing" and (more significantly) fundamentally transforming "human nature," and doing so with the same biotechnological means used by advocates of moderate enhancement (applied sparingly and with limitations in most cases), who are themselves still frightened of it [61-67].
}

enhanced existence past a certain point "distinctive," particular, beyond the human threshold?

Humanism itself, it appears, requires in its advanced stage the relinquishing of the metaphysical and always normative view of "human nature" on behalf of a seemingly more modest, careful, prudent, but also more fruitful consideration of consequences regarding different kinds of foreseeable enhancements. Provided they are not completely arbitrary, but are conditioned by our understanding of the past and the present, projections of humanity's future image through thought experiments in (science) fiction are in this respect unavoidable and extremely valuable [52]. The stories of Smurfs, Cyborgs and Changelings, therefore, should not be read as a warning that technology may rob us of our humanity, but as an invitation to debate the practical effects of some potential lines of enhancement leading towards a humanity which no longer need essencialization.

Open Access This article is distributed under the terms of the Creative Commons Attribution License which permits any use, distribution, and reproduction in any medium, provided the original author(s) and the source are credited.

\section{References}

1. Bostrom N, Roache R (2008) Ethical issues in human enhancement. In: Ryberg J, Petersen T, Wolf C (eds) New waves in applied ethics. Macmillan, New York, pp 120-152

2. Daniels N (2000) Normal functioning and the treatment-enhancement distinction. Camb Q Healthc Ethics 9:309-322

3. Coenen C (2013) Human enhancement. In: Boer T, Fisher R (eds) Human enhancement scientific, ethical and theological aspects from a European perspective. Church and Society Commission of CEC, Strasburg, pp 57-79

4. Moore P (2008) Enhancing me: the hope and the hype of human enhancement. Wiley, Chichester

5. Kurzweil R (2005) The singularity is near: when humans transcend biology. Viking, New York

6. Nietzsche F (2005) Thus spoke Zarathustra. Oxford World's Classics, Oxford

7. Allhoff F, Lin P, Moor J, Weckert J (eds) (2009) Ethics of human enhancement: 25 Questions \& Answers. US National Science Foundation. http://ethics.calpoly.edu/NSF_report.pdf. Accessed 13 June 2012

8. Ramez N (2005) More than human: embracing the promise of biological enhancement. Broadway Books, Portland

9. Bostrom N (2005) A history of transhumanist thought. J Evol Technol 14:1-25

10. Newman W (2004) Promethean ambitions: alchemy and the quest to perfect nature. University of Chicago Press, Chicago

11. Greely H (2006) Regulating human biological enhancements: questionable justifications and international complications. Santa Clara J Int Law 4:87-110

12. Juengst $E$ (1997) Can enhancement be distinguished from prevention in genetic medicine? J Med Philos 22:125-142

13. Toumey C (1992) The moral character of mad scientists: a cultural critique of science. Sci Technol Human Values 17:411-437

14. Stevenson R (1984 [1886]) The strange case of Dr. Jekyll and Mr. Hyde. In: The works of Robert Louis Stevenson. Spring Books, London, pp 643-687 
15. Shelley M (1818) Frankenstein; or, the modern Prometheus. Lackington, Hughes, Harding, Mavor, \& Jones, London. http:// books.google.rs/books?id=5twBAAAAQAAJ\&pg=PR $1 \&$ hl= sr\&source $=$ gbs_selected_pages $\&$ cad $=3 \# \mathrm{v}=$ onepage \&q\&f $=$ false. Accessed 12 Novembar 2006

16. Abrams J (2008) The dialectic of enlightenment in Metropolis. In: Sanders S (ed) The philosophy of science fiction film. The University Press of Kentucky, Lexington, pp 153-170

17. McMahon J (2008) The existential Frankenstein. In: Sanders S (ed) The philosophy of science fiction film. The University Press of Kentucky, Lexington, pp 73-89

18. Haynes R (2000) Celluloid scientists: futures visualised. In: Sandison A, Dingley R (eds) Histories of the future: studies in fact, fantasy and science fiction. Palgrave, New York, pp 34-50

19. Nabokov V (1989) The metamorphosis. http://www.kafka.org/index. php?id=191,209,0,0,1,0. Accessed 20 July 2012

20. Bostic A (1998) Automata: seeing cyborg through the eyes of popular culture, computer-generated imagery, and contemporary theory. Leonardo 31:357-361

21. Barad J, Robertson E (2001) The ethics of Star Trek. Harper Perennial, New York

22. Johnson-Smith J (2004) American science fiction TV: star trek, stargate and beyond. Tauris, London

23. Barrett M, Barrett D (2001) Star Trek: the human frontier. Routledge, New York

24. Brasher B (1996) Thoughts on the status of the cyborg: on technological socialization and its link to the religious function of popular culture. J Am Acad Relig 64:809-830

25. Boyd K (1996) Cyborgs in utopia: the problem of radical difference in Star Trek: The Next Generation. In: Harrison T, Projansky S, Ono K, Helford E (eds) Enterprise zones: critical positions on Star Trek. Westview Press, Boulder, pp 95-114

26. Larson D (1997) Machine as messiah: cyborgs, morphs, and the American body politic. Cinema J 36:57-75

27. Tirosh-Samuelson H (2011) Engaging transhumanism. In: Hansell G, Grassie W (eds) $\mathrm{H}+/-$ : transhumanism and its critics. Metanexus Institute, Philadelphia, pp 19-54

28. Slusser G (2009) Dimorphs and doubles: J.D. Barnal's Two cultures and the Tanshuman promise. In: Westfahl G, Slusser G (eds) Science fiction and the two cultures: essays on bridging the gap between the sciences and the humanities. McFarland, Jefferson, pp 96-129

29. Hayles N (1999) How we became posthuman: virtual bodies in cybernetics, literature, and informatics. University of Chicago Press, Chicago

30. Joy B (2000) Technology and humanity reach a crossroads. Bull Am Acad Arts Sci 53:25-27

31. Haraway D (1991 [1985]) A cyborg manifesto: Science, technology, and socialist-feminism in the late twentieth century. In: Haraway D (ed) Simians, cyborgs and women: the reinvention of nature. Routledge, New York, pp 149-181

32. Haraway D (1992) Ecce Homo, ain't (ar'n't) I a woman, and inappropriate/d others: the human in a post-humanist landscape. In: Butler J, Scott J (eds) Feminists theorize the political. Routledge, New York, pp 86-100

33. Haraway D (1996) Universal donor's in a vampire culture: it's all in the family: biological kinship categories in the twentieth-century US. In: Cronon W (ed) Uncommon ground: rethinking the human place in nature. Norton \& Company, New York, pp 321-366

34. Haraway D (1997) Modest_Witness@Second_Millennium.Fem aleMan(C) Meets Oncomouse ${ }^{\mathrm{TM}}$ : feminism and technoscience. Routledge, New York

35. Haldane J (1923) Daedalus or science and the future. A paper read to the Heretics [Cambridge, 4. April]. Berkeley, CA. 10. April 1993. http:// www.cscs.umich.edu/ crshalizi/Daedalus.html. Accessed 14 June 2012

36. Lee K (1999) The natural and the artefactual: the implications of deep science and deep technology for environmental philosophy. Lexington Books, Landham
37. Newman S (2003) Averting the clone age: prospects and perils of human developmental manipulation. J Contemp Health Law Policy 19:431-463

38. Grundy S (1998) Shapeshifting and berserkergang. In: Poster C, Utz $\mathrm{R}$ (eds) Translation, transformation, and transubstantiation. Northwestern University Press, Evanston, pp 104-122

39. Steiger B (1999) The werewolf book: the encyclopedia of shapeshifting beings. Visible Ink Press, Detroit

40. Graves R (1992 [1960]) The Greek myths. Penguin, London

41. Huxley J (1957) Transhumanism. World Tanshumanist Association. http://www.transhumanism.org/index.php/WTA/more/huxley/. Accessed 14 June 2012

42. Clarke B (2008) Posthuman metamorphoses: narrative and systems. Fordham University Press, New York

43. Bible TH (2009) RCK CyberServices. University Place, Washington

44. Pici Mirandulani I (1994 [1486]) Oratio de hominis dignitae. Filip Višnjić, Beograd

45. Gehlen A (1993 [1940]) Der Mensch. Seine Natur und seine Stellung in der Welt. Klostermann, Frankfurt am Main

46. Sartre J-P (1970 [1946]) L'existentialisme est un humanisme. Nagel, Paris

47. Sartre J-P (1982 [1943]) L'Être et le néant: Essai d'ontologie phénoménologique. Gallimard, Paris

48. Plessner H (1972) Der mensch als lebewesen. In: Rocek R, Schatz O (eds) Philosophische anthropologie heute. Beck, München, pp 51-64

49. Plessner H (1972) Homo absconditus. In: Rocek R, Schatz O (eds) Philosophische anthropologie heute. Beck, München, pp 37-50

50. Plessner H (1975 [1928]) Die stufen des organischen und der mensch. Einleitung in die philosophische Anthropologie. de Gruyter, Berlin

51. Carrel A (1966) L' homme, cet inconnu. Plon, Paris

52. Hughes J (2004) Citizen cyborg: why democratic societies must respond to the redesigned human of the future. Basic Books, New York

53. Sandel M (2007) The case against perfection: ethics in the age of genetic engineering. Cambridge, Belknap

54. Schneider S (ed) (2009) Science fiction and philosophy: from time travel to superintelligence. Wiley-Blackwell, West Sussex

55. Pinscy M (2003) Ethics and/as science fiction. Farileigh Dickinson University Press, Madison

56. Bernal J (1929) The world, the flesh \& the devil. An enquiry into the future of the three enemies of the rational soul. http://vserver1.cscs. 1sa.umich.edu/ crshalizi/Bernal/. Accessed 20 July 2013

57. Clynes M, Kline N (1995[1960]) Cyborgs and space. In: Gray C, Mentor S, Figueroa-Sarriera H (eds) The cyborg handbok. Routledge, New York, pp 43-54

58. Gray C (1999) Manfred clynes and the cyborg. In: Williams D (ed) MA festschrift for manfred clynes. MMB Music, Chicago, pp 46-49

59. Bostrom N (2008) Why I want to be a posthuman when I grow up. In: Gordijn B, Dhadwick R (eds) Medical enhancement and posthumanity. Springer, Dordrecht, pp 107-137

60. Inniss P (1998) Transhumanism: the next step? Council for Sekular Humanism. http://www.secularhumanism.org/library/aah/inniss_8 4.htm. Accessed 14 June 2012

61. Regis E (1990) Great mambo chicken and the transhuman condition: science slightly over the edge. Addison-Wesley, Reading

62. Harris J (1992) Wonderwoman and superman: the ethics of human biotechnology. Oxford University Press, Oxford

63. Bostrom N (2003) Human genetic enhancements: a transhumanist perspective. J Value Inq 37:493-506

64. Agar N (2004) Liberal eugenics: in defence of human enhancement. Blackwell, Malden

65. Bostrom N (2005) Transhumanist values. Rev Contemp Philos 4:87-101

66. Bostrom N (2005) In defence of posthuman dignity. Bioethics 19: 202-214

67. Bostrom N, Savulescu J (eds) (2010) Human enhancement. Oxford University Press, Oxford 